\title{
Pengaruh Physical Exercise terhadap Tingkat Stress pada Ibu Bekerja di Sekolah Tinggi Kesehatan
}

\author{
Prita Adisty Handayani ${ }^{1}$, Ratnasari ${ }^{2}$ \\ ${ }^{1,2}$ STIKES Telogorejo, Semarang, Indonesia \\ pritaadisty@stikestelogorejo.ac.id
}

\begin{abstract}
Introduction: The high rate of participation in working mothers must be balanced with health services so that working mothers can avoid occupational health problems, one of which is work stress. Stress in working mothers if not treated can cause symptoms both physiologically, psychologically and behaviorally. Dealing with work stress can be done using physical exercise. The purpose of this study was to analyze the effect of physical exercise on stress levels of working mothers as employees of high school health.

Methods: The research used a quasi-experimental method with one group pre-post-test design. Research's instrument used a job stress questionnaire with the value of the Alpha Chronbach validity and reliability test of 0.775 (> 0.06). The number of samples was 34 respondents with inclusion criteria of working mothers, moderate and severe stress levels, and single parent exclusion criteria and other stress therapies. Sampling techniques using purposive sampling and univariate analysis include the characteristics of respondents, namely age, length of work, work units, and workload. The bivariate analysis using the Wilxocon test.
\end{abstract}

Results: Through the Wilcoxon test it was found that there was an effect of physical exercise on the stress level of working mothers with a p value $=0.000$.

Conclusion: Physical exercise can make someone happier, have a positive response, maintained mental health, life satisfaction and good self-efficacy.

Keywords: Physical Exercise, Work Stress, Working Mother.

\section{Abstrak}

Pendahuluan: Tingginya angka partisipasi pada ibu bekerja tersebut harus diimbangi dengan pelayanan kesehatannya sehingga ibu bekerja dapat terhindar dari masalah kesehatan kerja salah satunya adalah stress kerja. Stress pada ibu bekerja apabila tidak diatasi dapat menimbulkan gejala baik secara fisiologis, psikologis maupun perilaku. Untuk mempertahankan diri dalam mengatasi stress kerja dapat dilakukan dengan menggunakan 
physical exercise. Tujuan pada penelitian ini adalah untuk menganalisis pengaruh physical exercise terhadap tingkat stress ibu bekerja di sekolah tinggi kesehatan.

Metode penelitian: Penelitian menggunakan metode quasi experiment dengan one group pre-post-test design. Instrumen penelitian menggunakan kuesioner stress kerja dengan nilai uji validitas dan reabilitas Alpha Chronbach 0,775 (>0,06). Jumlah sampel 34 responden dengan kriteria inklusi ibu bekerja, tingkat stress sedang dan berat, dan kriteria eksklusi single parent serta sudah melalukan terapi stress yang lainnya. Teknik sampling menggunakan purposive sampling dan analisis univariat meliputi karakteristik responden yaitu umur, lama kerja, unit kerja, dan beban kerja. Analisa bivariat menggunakan uji Wilxocon.

Hasil penelitian: Melalui uji Wilcoxon didapatkan bahwa ada pengaruh physical exercise terhadap tingkat stress ibu bekerja dengan nilai $p$ value $=0,000$.

Kesimpulan: Physical exercise dapat membuat seseorang menjadi lebih bahagia, memiliki respon positif, kesehatan mental yang terjaga, kepuasan hidup dan efikasi diri yang baik.

Kata kunci: Ibu Bekerja, Physical Exercise, Stres Kerja.

\section{PENDAHULUAN}

Indonesia sebagian besar penduduknya merupakan pekerja dan total pekerja wanita pada tahun 2014 adalah sebesar 47,08\% (Ritonga, 2017). Tingginya angka partisipasi pada ibu bekerja tersebut harus diimbangi dengan pelayanan kesehatannya sehingga ibu bekerja dapat terhindar dari masalah kesehatan kerja salah satunya adalah stress kerja.

Stress pada ibu bekerja dapat terjadi karena apabila terdapat masalah dalam proses koping individunya. Ibu bekerja yang mengalami stres umumnya akan merespon masalah tersebut melalui sistem koping. Sistem koping yang dapat muncul berfokus pada emosi, fisik dan masalah. Ketiga koping inilah yang apabila tidak sempurna akan mengakibatkan proses koping individu terhambat sehingga stres tidak dapat diatasi (Wilson, 2010). Hasil survei di Indonesia menunjukkan bahwa faktor pencetus stress kerja dapat berupa tempat dan kondisi kerja, ruangan yang tidak kondusif, beban kerja, tekanan kerja, hubungan interpersonal, konflik dengan teman, gaya kepemimpinan dalam suatu tempat kerja dan tidak adanya dukungan dari keluarga (Wuswa, 2013).

Stress pada ibu bekerja dapat berdampak pada fisiologis, psikologis dan perilaku. Gejala stress di tempat kerja dapat muncul seperti hilangnya rasa puas dalam bekerja, penurunan kinerja, hilangnya semangat selama bekerja, komunikasi tidak efektif, ketidaksesuaian dalam dalam mengambil keputusan, kurang berinovasi, dan tugas tidak terkelola dengan baik (Cahyani, 2008).

Peran perawat komunitas dalam mengatasi masalah stress kerja adalah 
sebagai edukator. Edukator berperan dalam memberikan pengetahuan, informasi dan pelatihan ketrampilan dalam upaya pencegahan penyakit dan peningkatan status kesehatan (Hapsari, 2013). Untuk mempertahankan diri dalam mengatasi stress kerja dapat dilakukan dengan menggunakan aktifitas fisik, yoga dan peregangan, relaksasi progresif, manajemen waktu, interpersonal skills dan cognitive/mental coping skills (Heart Stroke Foundation, 2013; NIOSH, 2008).

Physical exercise berupa senam aerobik bermanfaat untuk menurunkan masalah kesehatan kerja seperti kecemasan, stress, dan depresi akibat kerja. Sistem saraf perifer terutama parasimpatis yang akan mengakibatkan pembuluh darah vasodilatasi yang berdampak pada terjadinya penurunan tekanan darah sistolik dan diastolik sehingga seseorang akan merasakan rileks (Moniaga, Pangemanan, \& Rampengan, 2013).

Perbedaan penelitian ini dengan penelitian sebelumnya adalah pada responden penelitian dimana pada penelitian ini diberikan kepada ibu bekerja sedangkan pada penelitian sebelumnya pada pasien hipertensi, remaja dan lansia. Selain itu pada penelitian ini stress kerja merupakan hal yang akan dinilai, sedangkan pada penelitian sebelumnya belum ada yang membahas mengenai pengaruh intervensi terhadap tingkat stress kerja. Ibu bekerja memiliki masalah lebih kompleks dimana beban tanggung jawab kerja dan rumah yang apabila tidak diatas akan berdampak pada kesehatan ibu bekerja. Oleh karena itu, peneliti tertarik untuk meneliti pengaruh physical exercise terhadap tingkat stress pada ibu yang bekerja.

\section{METODE}

Penelitian menggunakan metode quasi experiment dengan one group prepost-test design (Dharma, 2011). Peneliti memilih responden sesuai dengan kriteria untuk kemudian dilakukan pre-test untuk mengukur tingkat stres pada kelompok ibu bekerja sebelum diberikan intervensi physical exercise. Peneliti kemudian melakukan post-test dengan mengukur tingkat stres kembali setelah intervensi physical exercise dilakukan. Intervensi physical exercise dilaksanakan sebanyak 2 kali sesi selama 60 menit yang terdiri dari pemanasan, gerakan inti, dan pendinginan.

Populasi pada penelitian ini adalah ibu bekerja di sebuah sekolah tinggi kesehatan di Semarang yaitu sejumlah 42 ibu bekerja. Kriteria inkluasi pada penelitian ini adalah ibu bekerja, terdaftar sebagai karyawan di sebuah sekolah tinggi kesehatan di Semarang, tingkat stress sedang dan berat dan mengikuti seluruh kegiatan physical exercise. Kriteria eksklusi pada penelitian ini adalah single parent dan sudah mengikuti terapi stress yang lain.

Teknik pengambilan sampel menggunakan purposive sampling. Sampel yang diambil tersebut dipilih berdasarkan maksud dan tujuan penelitian dimana responden yang digunakan tersebut memiliki informasi atau data sesuai yang diinginkan oleh peneliti (Dharma, 2011). Jumlah sampel 34 orang dengan menggunakan rumus Slovin dimana 
terdapat responden yang drop out karena tidak mengikuti keseluruhan kegiatan physical exercise sebanyak empat orang.

Instrumen penelitian menggunakan Kuesioner Stress Kerja yang sebelumnya sudah dilakukan pengukuran uji validitas dan reabilitas dengan hasil nilai Alpha Chronbach 0,775 (>0,06).

Analisis univariat meliputi karakteristik responden meliputi umur, lama kerja, unit kerja, dan beban kerja. Hasil uji normalitas data menggunakan uji Shapiro-Wilk dengan taraf signifikan $(\alpha)$ yang digunakan adalah $5 \%$ didapatkan hasil nilai $p$ value sebesar $0,000(<0,05)$ sehingga dapat disimpulkan data berdistribusi tidak normal. Berdasarkan hasil uji normalitas, peneliti menggunakan uji Wilxocon untuk analisis bivariat.

Sebelum penelitian dilaksanakan peneliti mengajukan uji etik kepada tempat penelitian dengan cara mempresentasikan proposal penelitian dan setelah itu peneliti diberikan surat keterangan lolos uji etik.

\section{HASIL}

1. Analisa Univariat

a. Karakteristik Responden

Tabel 1. Distribusi Frekuensi Karakteristik Responden Ibu Bekerja Berdasarkan Usia, Unit Kerja, Lama Bekerja, dan Beban Kerja di Sekolah Tinggi Kesehatan di Semarang $(n=34)$

\begin{tabular}{clcc}
\hline No & \multicolumn{1}{c}{ Variabel } & f & \% \\
\hline 1. & Umur & & \\
& $-\leq 39$ tahun & 21 & 61,7 \\
& $->40$ tahun & 13 & 38,3 \\
\hline 2. & Lama Kerja & 24 & 70,6 \\
& $-\leq 14$ tahun & 10 & 29,4 \\
& $->15$ tahun & & \\
\hline
\end{tabular}

3. Unit Kerja

\begin{tabular}{llcc}
\hline No & \multicolumn{1}{c}{ Variabel } & f & \% \\
\hline & - Pendidik & 20 & 58,8 \\
& - Tenaga Kependidikan & 14 & 41,2 \\
\hline 4. & Beban Kerja & & \\
& - Rendah & 4 & 11,8 \\
& - Tinggi & 30 & 88,2 \\
\hline
\end{tabular}

Tabel.1 menunjukkan bahwa 61,7\% responden berusia lebih dari 39 tahun, lama kerja menunjukkan $70,6 \%$ sudah bekerja selama kurang dari atau sama dengan 14 tahun. Unit kerja responden menunjukkan 58,8\% adalah pendidik dan beban kerja pada kedua kelompok menunjukkan $88,2 \%$ dalam beban kerja yang tinggi.

b. Tingkat Stress sebelum Physical Exercise

Tabel 2. Diskripsi Tingkat Stress Ibu Bekerja di Sekolah Tinggi Kesehatan Sebelum diberikan Physical exercise $(n=34)$

\begin{tabular}{|c|c|c|}
\hline Kelas & Rata-Rata & $\begin{array}{c}\text { Kategori Tingkat } \\
\text { Stress }\end{array}$ \\
\hline Stress pre- & 2,07 & Sedang \\
\hline
\end{tabular}

Tabel 2 menunjukkan bahwa tingkat stress pada ibu yang bekerja di Sekolah Tinggi Kesehatan sebelum diberikan physical exercise dalam kategori tingkat stress sedang.

Tabel 3. Diskripsi Tingkat Stress Ibu Bekerja di Sekolah Tinggi Kesehatan Sesudah Diberikan Physical Exercise $(n=34)$

\begin{tabular}{|c|c|c|}
\hline Kelas & Rata-Rata & $\begin{array}{c}\text { Kategori Tingkat } \\
\text { Stress }\end{array}$ \\
\hline Stress Post & 1,14 & Ringan \\
\hline
\end{tabular}

Tabel 3 menunjukkan bahwa tingkat stress pada ibu yang bekerja di Sekolah Tinggi

Prita Adisty Handayani, dkk., Pengaruh Physical Exercise terhadap Tingkat Stres Ibu Bekerja 
Kesehatan di Semarang sesudah diberikan intervensi berupa physical exercise dalam kategori tingkat stress ringan.

Tabel 4. Pengaruh Physical Exercise terhadap Tingkat Stress Ibu Bekerja di Sekolah Tinggi Kesehatan.

\begin{tabular}{|l|c|c|}
\hline \multicolumn{1}{|c|}{ Tingkat Stress } & $\mathrm{Z}$ & P value \\
\hline $\begin{array}{l}\text { Stress Pre-Stres } \\
\text { Post }\end{array}$ & $-4,973$ & 0,000 \\
\hline
\end{tabular}

Tabel 4 menunjukkan hasil bahwa ada pengaruh physical exercise terhadap tingkat stress ibu bekerja.

\section{PEMBAHASAN}

Hasil uji statistik stress pada ibu bekerja sebelum diberikan intervensi berupa physical exercise didapatkan hasil berada dalam tingkat stress sedang. Stress pada ibu bekerja dapat terjadi karena dua tanggungjawab yang harus dilaksanakan antara bekerja di rumah dan di kantor dan juga dikarenakan beban kerja yang tinggi. Stres oleh tubuh direspon dengan mengaktifkan sistem kardiorespirasi, sistem locus ceruleus (LC/norepinephrin (NE), sistem metabolisme dan HPA axis. Aktifnya hipotalamus-puitutary-adrenal axis (HPA), menimbulkan conditioning stimuli pada alur limbic-hipotalamuspuitutary-adrenal axis (LHPA axis), kemudian merangsang hipotalamus dan menyebabkan disekresinya hormon corticotrophin relesing hormone (CRH), merangsang hipotalamus untuk sekresi ACTH (Sugiharto, 2012).

Peningkatan sekresi ACTH, menyebabkan meningkatnya sekresi, kortisol. Hormon tersebut dikeluarkan Prita Adisty Handayani, dkk., Pengaruh Physical Exercise terhadap Tingkat Stres Ibu Bekerja untuk menjaga homeostatis dalam menghadapi stres, baik fisik maupun psikologis. Dalam batas tertentu peningkatan kortisol digunakan sebagai upaya untuk menghadapi tuntutan baru (cope) dengan peningkatan kebutuhan energi yang diakibatkan oleh stresor olahraga, baik stresor fisik maupun psikologis menyebabkan peningkatkan sistem kardiorespirasi dan neurohormonal, sebagai refleksi dari respon sistem saraf otonomi salah satunya sistem saraf simpatik (Sugiharto, 2012).

Stress kerja sering dipersepsikan sebagai tekanan hidup. Ibu bekerja yang mengalami stress sering merasakan kehidupannya terasa sulit dan berat (Noor, Rahardjo, \& Ruhana, 2016). Faktor terjadinya stres pada ibu bekerja dapat timbul dari tempat kerja maupun rumah atau lingkungan keluarga. Apabila ibu bekerja belum mampu mengelola waktu untuk urusan keluarga dan pekerjaan, maka akan menimbulkan konflik yang sering disebut konflik peran ganda (Akbar, 2017). Faktor beban kerja yang berlebih dan kurangnya apresiasi masyarakat terhadap pekerjaan yang dijalani ibu bekerja juga dapat mengakibatkan ibu mengalami stress terhadap pekerjaannya (Kusumajati, 2010).

Faktor lain yang berasal dari rumah atau keluarga yaitu seperti adanya pemaksaan untuk tetap bekerja baik pada suami ataupun istri guna mempertahankan gaya hidup yang tinggi (Kusumajati, 2010). Faktor-faktor pencetus stress tersebut apabila tidak segera ditangani akan berdampak pada psikologis, fisik dan perilaku ibu yang dapat mengakibatkan 
masalah baik di tempat kerja maupun di rumah (Wilson, 2010).

Stress memiliki dampak langsung ke dalam diri yaitu muncul gejala letih yang berlebihan, mudah tersinggung, dan muncul rasa gelisah (Rohaedi, Sri, \& Rahmawati, 2017). Dampak lain yang muncul akibat stres kerja menurut International Labor Organization (2016) yaitu stress kerja dapat mempengaruhi kesehatan baik kesehatan mental seperti cemas dan depresi sehingga dapat mengakibatkan penyakit jantung dan masalah pada muskuloskeletal. Dampak stress terhadap kinerja ini didukung oleh penelitian yaitu terdapat hubungan antara stress kerja dengan kinerja perawat dalam pelaksanaan pelayanan keperawatan (Fajrillah \& Nurfitriani, 2016).

Perilaku negatif yang perlu diwaspadai dari dampak stress ini adalah munculnya gejala susah tidur, diet yang tidak sehat, dan penggunaan obat-obatan yang dilarang, sedangkan perilaku positif yang dapat muncul apabila koping ibu baik adalah ibu akan menerima dan ikhlas serta bahagia dalam melaksanakan tugasnya baik di tempat kerja atau di rumah. Penatalaksanaan untuk mangatasi stress di tempat kerja dapat berupa aktivitas fisik (Rahmawati, 2009). Kegiatan aktifitas fisik yang dapat mengatasi stress sekaligus dapat meningkatkan kesehatan tubuh adalah physical exercise (senam aerobik) (Purwanto, 2011).

Hasil uji statistik tentang pengaruh physical exercise terhadap tingkat stress pada ibu bekerja didapatkan data bahwa tingkat stress pada ibu bekerja sebelum dan setelah diberikan intervensi berupa physical exercise menurun dari tingkat stress sedang ke tingkat stress ringan. Physical exercise yang dilakukan secara porposional dapat menurunkan beberapa masalah akibat stress kerja seperti kecemasan, stress, dan depresi. Penurunan tingkat stress dapat merangsang sistem saraf perifer sehingga mengakibatkan pelebaran penampang pembuluh darah dan pelebaran tersebut mengakibatkan penurunan darah sistolik dan diastolik (Moniaga, Pangemanan, \& Rampengan, 2013).

Physical exercise berupa senam aerobik dapat meningkatkan daya tahan tubuh terhadap penyakit karena antibodi dalam tubuh dapat terbentuk selama proses physical exercise tersebut (Purwanto, 2011). Selain itu melalui physical exercise, pembuluh darah menjadi rileks dan tidak kaku sehingga tekanan darah dapat menurun (Indrawati, 2017).

Hasil penelitian lain disampaikan bahwa dengan adanya kegiatan physical exercise dapat membuat seseorang menjadi lebih bahagia, memiliki respon positif, kesehatan mental yang terjaga, kepuasan hidup dan efikasi diri yang baik (KhazaeePool, Sadeghi, Majlessi, \& Forounshani, 2014). Penelitian lain menyimpulkan bahwa dengan physical exercise dapat memunculkan kejernihan pikiran, lebih fokus, dan suasana hati yang energik sehingga akan memperluas fungsi sosial (Kim \& Mckenzie, 2014).

\section{DAFTAR PUSTAKA}

Akbar, D. A. (2017). Konflik peran ganda karyawan wanita dan stres kerja. 
Jurnal Kajian Gender dan Anak, 12, 33-48.

Cahyani, L. S. (2008). Analisis hubungan antara stress kerja dan kinerja karyawan di PT. Unitex Tbk. Bogor. Skripsi. Institut Pertanian Bogor.

Dharma, K. K. (2011). Metodologi penelitian keperawatan. Jakarta: Trans Info Media.

Fajrillah, \& Nurfitriani. (2016). Hubungan stres kerja dengan kinerja perawat pelaksana dalam melaksanakan pelayanan keperawatan di Instalasi Gawat Darurat Rumah Sakit Umum Anutapura Palu. Jurnal Keperawatan Sriwijaya, 3(2), 16-24.

Hapsari, R. W. (2013). Hubungan peran perawat sebagai edukator dengan pemenuhan kebutuhan rasa aman pasien di ruang rawat inap Rumah Sakit Umum dr. H. Koesnadi Kabupaten Bondowoso. Skripsi. Universitas Jember.

Heart Stroke Foundation. (2013). Coping with stress. Canadian Mental Health Association. Diperoleh diperoleh dari https://www.heartandstroke.ca//media/pdf-files/canada/other/copingwith-stress-en.ashx

Indrawati, L. (2017). Pengaruh senam aerobik terhadap penurunan tekanan darah pada penderita hipertensi. Diperoleh dari https://media.neliti.com/media/public ations/276542-pengaruh-senamaerobik-terhadap-penurunaa2eadcb4.pdf

International Labor Organization. (2016). Workplace stress: A collective challenge. Geneva: ILO Publications. Diperoleh dari www.ilo.org/safeday
Jum'ati, N., \& Wuswa, H. (2013). Stres kerja (occupational stress) yang mempengaruhi kinerja individu pada Dinas Kesehatan Bidang Pencegahan Pemberantasan Penyakit dan Penyehatan Lingkungan (P2P-PL) di Kabupaten Bangkalan. Neo-Bis, 7(2).

Khazaee-Pool, M., Sadeghi, Majlessi, F., \&Foroushani, A. R. (2014). Effects of physical exercise programme on happiness among older people. Journal of Pscychiatic and Mental Health Nursing, 22(1), 47-57. doi: 10.1111/jpm. 12168

Kim, J., \& Mckenzie, L. A. (2014). The impacts of physical exercise on stress coping and well-being in university students in the context of leisure. Health, 6, 2570-2580. doi: 10.4236/health.2014.619296

Kusumajati, D. A. (2010). Stres kerja karyawan. Humaniora, 1(45), 792800 .

Moniaga, V., Pangemanan, D. H. C., \& Rampengan, J. J. (2013). Pengaruh senam bugar Lansia terhadap tekanan darah penderita hipertensi di BPLU Senja Cerah Paniki Bawah. Jurnal EBiomedik, 1(1), 785-789.

NIOSH. (2008). Occupational hazards in hospitals. Columbia: DHHS NIOSH Publisher.

Noor, N. N., Rahardjo, K., \& Ruhana, I. (2016). Pengaruh stres kerja dan kepuasan kerja terhadap kinerja karyawan (Studi pada karyawan PT JasaRaharja (Persero) Cabang Jawa Timur di Surabaya), 31(1), 9-15.

Purwanto. (2011). Dampak senam aerobik terhadap daya tahan tubuh dan penyakit. Jurnal Media Ilmu 
Keolahragaan Indonesia, 1, 1-19.

Rahmawati, S. (2009). Analisis stres kerja

karyawan pada PT Bank Rakyat

Indonesia (Persero) Tbk Cabang

Bogor. Jurnal Manajemen. 1(1), 111-

122.

Ritonga, R. (2017). Kebutuhan data

ketenagakerjaan untuk pembangunan

berkelanjutan. Diperoleh dari

http://www.ilo.org/wcmsp5/groups/pu

blic/---asia/---ro-bangkok/---ilo-

jakarta/documents/presentation/wcms

_346599.pdf

Rohaedi, S., Sri, S., \& Rahmawati, N. M.

(2017). Gambaran tingkat stres dan

indikator stres pada remaja yang

melakukan pernikahan dini di wilayah

kerja Puskesmas Parongpong

Kabupaten Bandung Barat. Skripsi.

Universitas Pendidikan Indonesia.

Sugiharto. (2012). Fisioneurohormonal

pada stresor olahraga. Jurnal Sains

Psikologi, 2(November), 54-66

Wilson, D. R. (2010). Stress management

for adult survivors of childhood

sexual abuse. Western Journal of

Nursing Research, 32(1), 103-127.

doi: 10.1177/0193945909343703 